\title{
Impact of COVID-19: Global Environment, Indian Economy and Construction Sector
}

\author{
Satish Tanaji Chavhan, Sandip Srivastava \\ DOI: 10.29322/IJSRP.11.02.2021.p11036 \\ http://dx.doi.org/10.29322/IJSRP.11.02.2021.p11036
}

\begin{abstract}
After the outbreak of COVID-19 in Wuhan, China, virus has spread like a fire in almost all the countries. Many countries are still suffering with thousands of casualties and to cop up with this problem, countries have taken several giant steps. Due to which global crises occurred in almost all business environments.

The aim of this research to highlight the impact of COVID-19 on Indian Construction Sector and on global economy as well as on global environment. Our research shows that there is a huge impact on economy with drastic decrease in GDPs of major countries during the lockdown and how different sectors are suffering from COVID-19. This research is mainly focused on the construction sector because construction sector is second highest contributor in industrial sector for India's GDP as per Ministry of Statistics and Program Implementation (2019-20). Our research also pointed out that how human activities are disturbing the environment by showing the positive impact on environment due to decrease in human activities during lockdown. However these positive impacts will no longer survive because many economies are slowly coming on track and human activities are increasing again.
\end{abstract}

\section{INTRODUCTION}

$\mathrm{T}$ This was third time in the decade, the virus from the family of coronaviruses created pandemic situation. First coronavirus SARS which was emerged from southern China in 2002 and spread to 28 countries. Total infected people by July 2003 were around 8,000, and 774 died. Second Coronavirus MERS (Middle East Respiratory Syndrome) emerged in 2012 from Saudi Arabia. Spread in Middle East countries and infected 2,500 people. MERS coronavirus was less transmittable than its SARS but was more deadly, killed almost 858 people. On late 2019 few people got infected by zoonotic virus in Wuhan city, China and later on spread in complete Wuhan city and then in complete world. This Virus is highly transmittable as well as deadly compared to SARS and MERS. Later on named as Corona Virus Disease 2019 (COVID-19). In just 3 month, COVID-19 infected nearly 1 million people and 50,000 died. By six months, cases exceeded 10 million and more than 500,000 people were dead. Because of increased in number of increased cases and number of deaths in a very short, World Health Organization (WHO) declared COVID-19 as a pandemic on March 11, 2020. On 1st sept confirmed cases reached over 25,508,000 with recorded deaths were 851,000. On 21st Dec 2020 confirmed cases reached over 96,971,000 with recorded deaths were 2,077,000 and continued to rise (Pharmaceutical Technology). Scientists have observed the worst thing about first wave of COVID-19 is that $40 \%$ of the people those who are infected with COVID-19 can transmit the virus to others without ever having symptoms this disease. The mutated COVID-19 virus is $70 \%$ more transmittable.

The top 7 countries in number of deaths due to COVID-19 are United States (US), Brazil, India, Mexico, UK, Italy and France. It was observed that the rate of increase of COVID-19 cases are extremely high in initial days. Particularly for those countries who had not imposed lockdown. Let us understand the importance of lockdown. European countries including Italy, United Kingdom, France, Spain, Germany, Switzerland, Portugal etc. are badly hit by COVID-19. In Italy, First case was recorded on 30 Jan, first death recorded on 21st February and nationwide lockdown imposed on 9th March till then 9,172 cases were recorded. But it was too late to take decision. In next 10 days cases rose to 40,000. United States (US) took 4 weeks to impose lockdown. Power is not centralized in US, so the national lockdown was not easy to do plus lack of knowledge on how serious the outbreak was.

After declaring the COVID-19 as a pandemic, from 19th march 2020 different states started imposing lockdown. By that time, confirmed cases rose to 14,000 and in next 10 days cases exceeded to 200,000. Whereas lesson learned from European countries and US, Indian government had implemented complete lockdown nationwide on 25th march 2020. At that time confirmed cases were only 516. Results in slow increase in COVID-19 cases. Some researchers says that the reason behind the less increase in confirmed cases are less testing. Daily new cases are started decreasing in many highly impacted countries in august 2020 and world's number of new cases are getting flatten. On the other hand, after 74 days of lockdown Indian government had decided to lift lockdown from 8th June 2020. Till that day number of cases per day was around 8,000. It was observed that the number of COVID-19 cases per day drastically increased to 80,000 cases till 1st Sept 2020. Only the satisfactory thing for India is, In spite of having second highest population (1352.62 Million) in the world, deaths are 111.04 per 1 million population and country stands at 76th position among 150 country list (Statista. Sept-2020) which is far better than developed countries. Union Health Ministry of India stated that the successful implementation of Centre's strategic and graded 'Test, Track and Treat' approach has results in higher recoveries and lower fatality. Recovery rate has increased to $96.56 \%$ and fatality rate decreased to $1.44 \%$ till 17 th January 2020 . (MoHFW). But the number of cases in India is still increasing is the matter of concern. 
Human activities are suddenly decreased in in all over the world due to lockdown and there has been drastic improvement observed in global environment. Nitrogen dioxide (NO2) and Sulfur Dioxide (SO2) level significantly decreased across the world, especially in the countries like India and China. Both the countries are at the top for GHG emission. SO2 and NO2 pollutes the air mainly from vehicle smoke and the combustion of fossil fuel in industrial processes like Coal based thermal Power Plant. In India, the level of NO2 dropped to $40-50 \%$ and level of SO2 dropped to $40 \%$ less in the month of April compared to the same time last year (ESA). Though the lockdown have been lifted slowly throughout the world, economic activities were still stalled. There has been a huge impact on global economy because of restriction of economic activities. Except China, all developed as well as developing countries including US, Germany, Canada, Italy have showed negative GDP in Q1 2020-21. India's GDP shrank by 23.9\% which is lowest in the world. Second lowest GDP recorded by UK i.e. 21.7\%. National Statistics Office (NSO) has published estimate of Gross Domestic Product of Q1 2020-21. Almost all the sectors except agriculture sectors are highly affected by lockdown. Study focused on construction sector of India because the contraction percentage over previous year observed in construction sector in maximum i.e. $-50.03 \%$ among all the sectors.

\section{IMPACT OF COVID-19 ON ENVIRONMENT}

Since last few decades, complete world is suffering from air pollution, especially urban areas. The report indicates that the $8 \%$ of death in the world is because of air pollution (WHO). Data published by World Health Organization for top 50 most polluted cities in the world based on the air quality. Air-quality tracking devices worldwide tracked the levels of hazardous particulates. PM2.5 is the most harmful in nature which contains tiny particles. These particles are small enough to enter the bloodstream through the lungs which contributes 7 million premature deaths per year (WHO). Transport, power plants, road dust, all types of industries, construction activities and residential activities are the major contributors to the air, water and noise pollution. COVID-19 forced world for complete lockdown. This period is like reset period for environment. The impact of COVID-19 is categorized into two parts. One is positive and second is negative. No doubt the positive impacts are at higher side due to restriction of human activities but there are negative impacts too which needs to be discuss.

\section{A. Positive Impacts:}

Before COVID-19, the percentage of CO2 was increased by 1\% per year in previous decade. Level of So2 and NO2 is also increased significantly in urban areas in few decades. In the month of February many countries declared partial/ complete lockdown. By the end of March, almost all the countries across the world imposed lockdown to avoid spread of COVID-19. In March, there was no positive change in environment, but suddenly the drastic changes have been observed month of April.

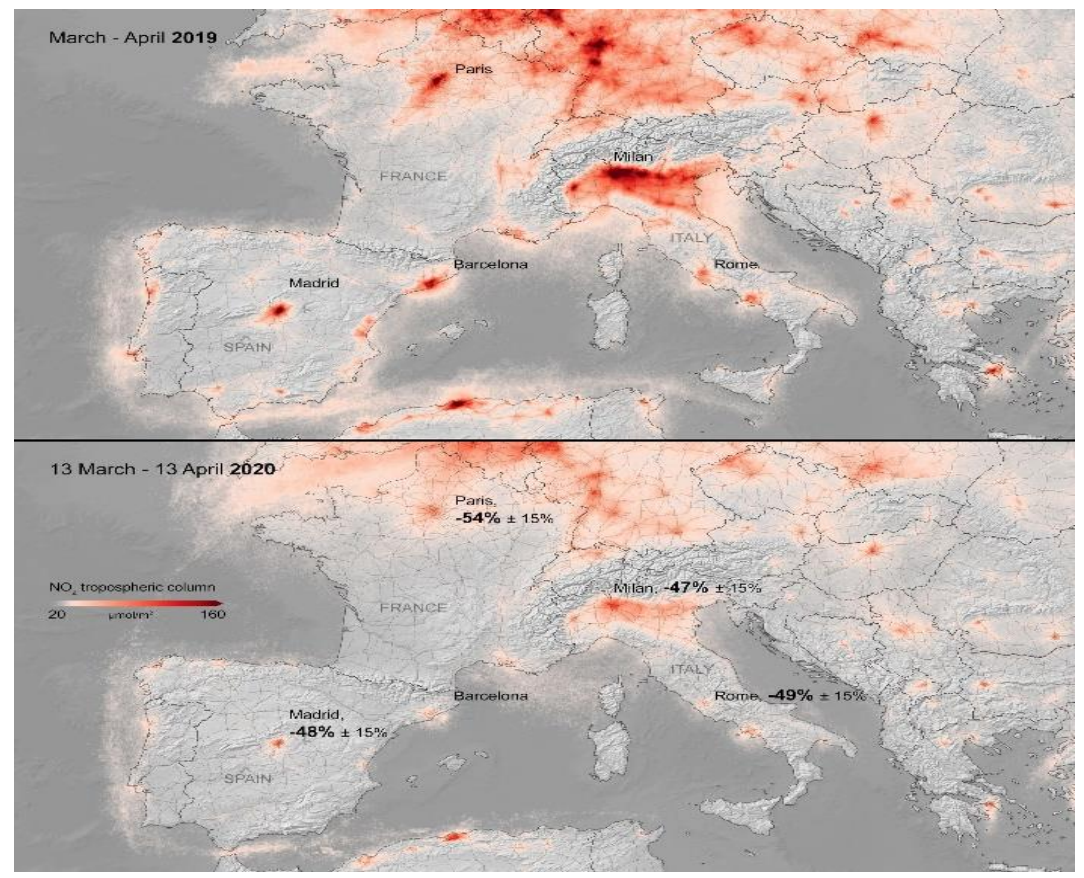

Fig. 1: Satellite image of NO2 concentrations over Europe

Satellite images published by NASA and European Space agency (ESA) clearly shows improvement in level of SO2 and NO2. 


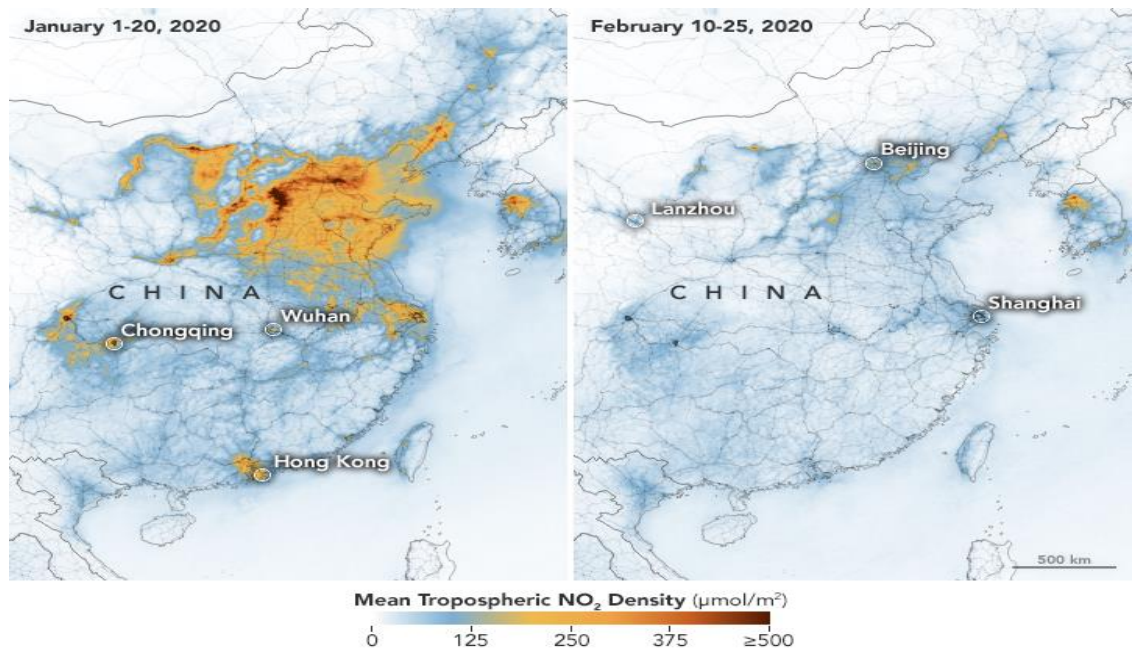

Fig 2: Satellite image of China (Pre-lockdown Vs Post Lockdown)

Observed changes were not only for a particular country or region, improvement was all over the world.

In China, 95 out of 324 cities were in lockdown. The data shows that, after 1 month of lockdown, the level of PM2.5 declined by $24 \%$ and Air Quality Index improved by 22\% (CAMS 2020). The amount of NO2 was decreased by $22.8 \mu \mathrm{g} / \mathrm{m} 3$ in Wuhan and 12.9 $\mu \mathrm{g} / \mathrm{m} 3$ in China. India is at the top for the contribution of pollution globally. WHO had published the ranking of top 50 most pollutant cities in the world in 2018. In that, total 14 cities are from India among top 20 cities. Central Pollution Control Board (CPCB) has recorded data for NCR in India from 16th march 2020 to 15th April 2020 and 78\% cities showed good results during the lockdown.

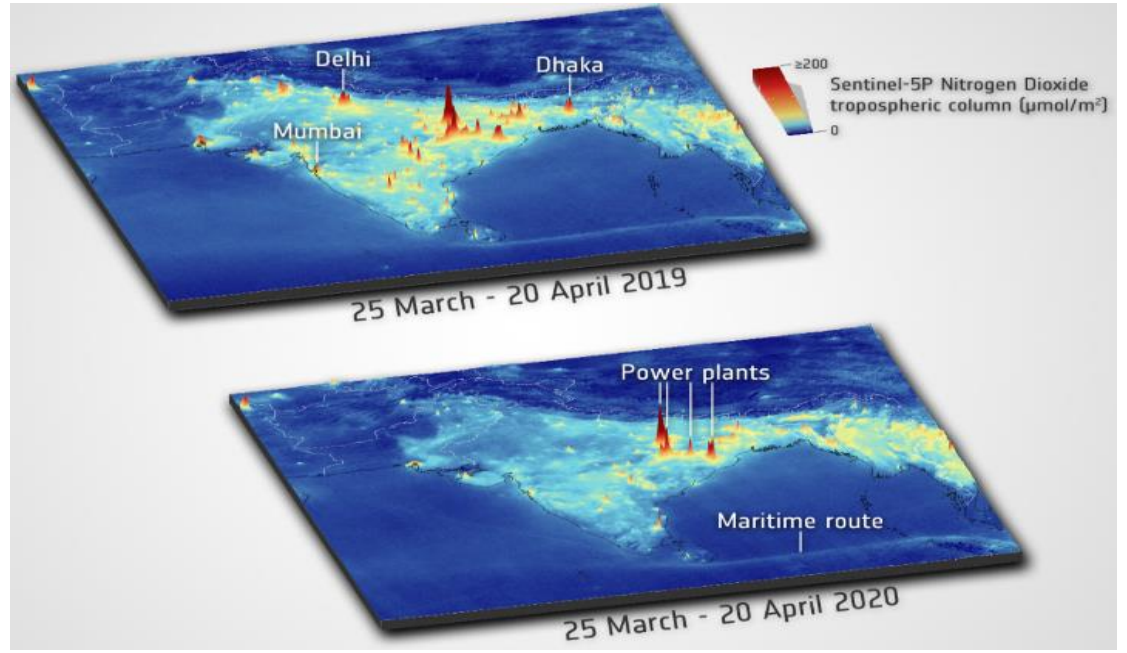

Fig. 3: Satellite image of NO2 Concentration over India (Source- ESA)

The data generated for Delhi from 38 stations which gave following results.

Table 1. Level of PM10, PM2.5, SO2 and NO2 in NCR

\begin{tabular}{|l|l|l|l|l|}
\hline Area & PM10 & PM2.5 & SO2 & NO2 \\
\hline Delhi & $48 \%$ & $46 \%$ & $17 \%$ & $56 \%$ \\
\hline Gurgaon & $54 \%$ & $54 \%$ & $14 \%$ & $50 \%$ \\
\hline Faridabad & $60 \%$ & $55 \%$ & $47 \%$ & $17 \%$ \\
\hline Noida & $48 \%$ & $48 \%$ & $10 \%$ & $68 \%$ \\
\hline Ghaziabad & $60 \%$ & $54 \%$ & $22 \%$ & $60 \%$ \\
\hline
\end{tabular}

From above date it is clear that there is a significant improvement in PM10, PM2.5, SO2 and NO2. NO2 level in Faridabad was little bit higher side due to the presence of gas-based power plants near Faridabad.

To analyse the impact of COVID-19 on water pollution, data has been collected from 36 Real Time Water Quality Motoring Systems on river Ganga and its tributaries. It was found that the level of dissolved oxygen level has increased and the level of nitrate 
has decreased after lockdown (22 March-15 April, 2020) compared to pre-lockdown (15-21 March. 2020). Lockdown phase was further sub-divided into Week 1:- 22-28 March, 2020, Week 2:- 29 March to 4 April, 2020, Week 3:- 5-11 April to, 2020, and (iv)

Week 4:- 12-15 April, 2020.

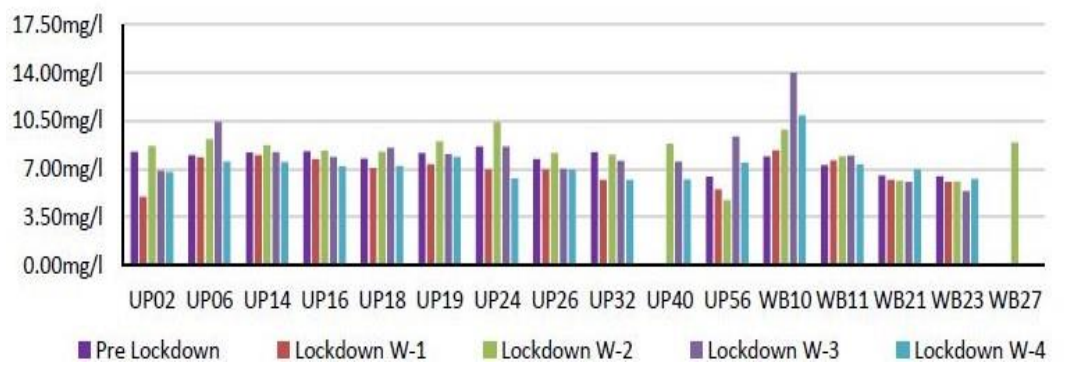

Fig 4: Changes in Dissolved O2 (Pre \& Post Lockdown)

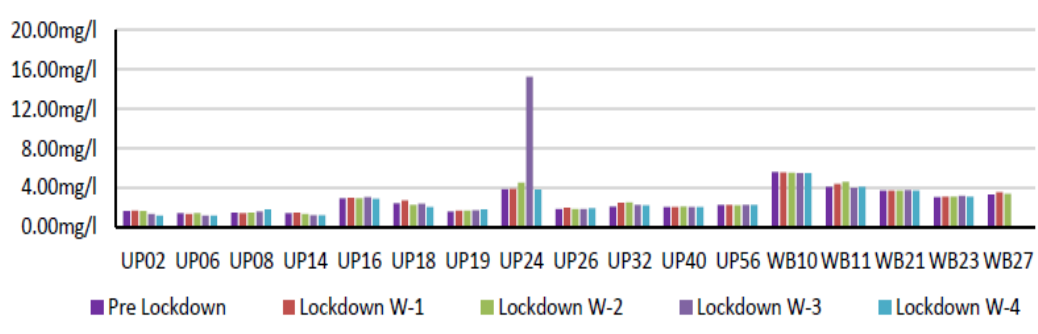

Fig. 5: Changes in BDO (Pre and Post Lockdown)

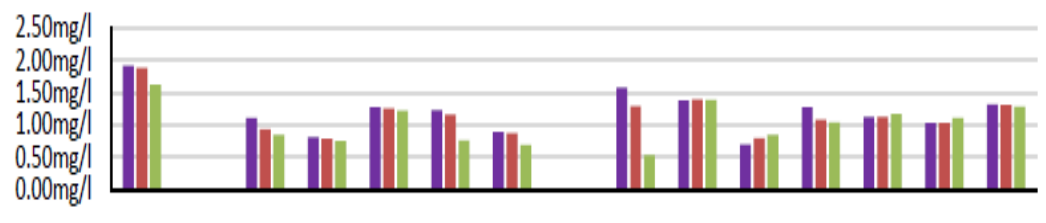

UP02 UP06 UP08 UP14 UP16 UP18 UP19 UP24 UP26 UP32 UP40 UP56 WB10 WB11 WB21

Pre Lockdown Lockdown W-1 Lockdown W-2

Fig. 6: Nitrate Level (Pre and Post Lockdown)

Dissolved Oxygen (DO) level was at lower side in the first week of lockdown because of heavy rainfall but there was a significant improvement in DO in second week of lockdown at almost every monitoring station. There was no significant change in Biochemical Oxygen Demand (BOD). In fact, there was slight increase in BDO was observed at downstream stretch (West Bengal) and minor drop at Utter Pradesh monitoring station. Since the industrial activities were restricted, significant drop (2\% to $66 \%)$ in Nitrate level was observed except at UP32, WB 10, WB11 and WB21.

\section{B. Negative Impacts}

COVID-19 forced world to take preventive measures to avoid spread of Corona Virus. WHO has recommended use of hand sanitizer, Face mask, surgical hand gloves, face shield etc. This results in increase in biomedical waste. If these waste are not properly disposed or recycled, it may create the hazardous situation to all the species. CPCB has issued guidelines for treating, handling and disposing of COVID-19 biomedical wastes through authorized Common Biomedical Waste Treatment Facilities (CBWTFs) under BMWM Rules, 2016 (CPCB). The major source of biomedical waste are Quarantine Camps or Quarantine-homes, Healthcare Facilities, Home-care, Sample Collection Centers, Laboratories etc. data collected from BMW facilitiesCOVID-19 biomedical waste generation increased drastically from June-2019. To track the COVID-19 waste generation CPCB has developed software named "COVID19BWM". This software supports Android Mobile and Web versions. The application was designed for Common Biomedical Waste Treatment and Disposal Facility (CBWTF), State Pollution Control Boards etc. CPCB has also issued notice to 108 facilities for not using this tracking application. COVID-19 BMW were 3025 tons, 4253 tons and 5238 tons in June, July and August respectively. The number of Common Biomedical Waste Treatment Facilities did not increase as compared to the rate of increase in waste generation. In June-2020, CBWTFs were 190 in august-2020 CBWTFs are 198 (CPCB). There is a need to establish more number of CBWTFs in India. 


\section{IMPACT OF COVID-19 ON ECONOMY}

COVID-19 plunged entire world into global economic crises. Most of the economies are on ventilation now. Supply chains, trade and finance have been disrupted completely, the public health crisis has escalated in almost every country. According to World Bank forecast global economy may shrink by $5.2 \%$ this year. Developed countries are not the exception in this slow down. Developed countries like US, Germany, Canada, and Italy have showed negative GDP in Q1 and Q2 of 2020-21. Since the lockdown was declared from 25th March 2020 by India's Prime Minister, impact of lockdown was not reflected in 4th quarter of 2019-2020. India's GDP in Q4 20192020 was 4.1, although this was lowest GDP for India in last 11 years.

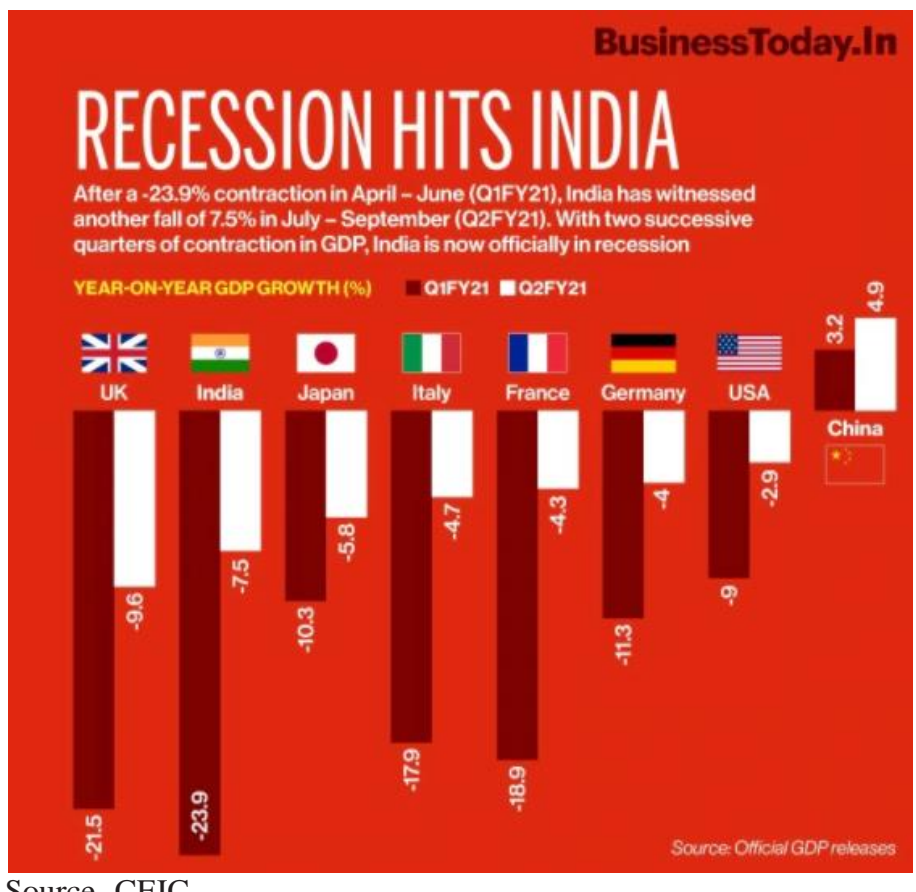

Fig. 7: GDP of Major countries in Q1 and Q2

Q1 of 2020-21 was worse than expected contraction. Market forecast was of $-18.3 \%$ contraction but actual figure was devastating which was $-23.9 \%$ (year on year) declared by National Statistical Office (NSO), Ministry of Statistics and Programme Implementation). Q1, 2020-21 estimate expenditure on GDP was 26.9 Lakh crore as against 35.35 Lakh Crore in Q1 of 2019-2020. If economy shows negative GDP for continuous 2 quarters, it will be considered as recession. In Q2, technically India entered in recession. Data published by NSO on 27 August 2020 India's GDP narrowed down to -7.5 (Year on Year) (NSO). To highlight the impact of lockdown o different industry, data of first quarter is shown in below table.

Table 2. Estimates of Expenditures on GDP in Q1 (at 2011-12 Prices) (In Crores)

\begin{tabular}{|l|r|r|l|l|}
\hline \multirow{2}{*}{ Industry } & \multicolumn{4}{c|}{ April-June (Q1) } \\
\cline { 2 - 5 } & & $\mathbf{2 0 1 9 - 2 0}$ & $\mathbf{2 0 2 0 - 2 1}$ & \multicolumn{1}{c|}{ Rates of GDP (\% } \\
\cline { 3 - 5 } & & & $\mathbf{2 0 1 9 - 2 0}$ & $\mathbf{2 0 2 0 - 2 1}$ \\
\hline Pvt. Consumption & $19,92,967$ & $14,61,164$ & 56.4 & 54.3 \\
\hline Gov. Consumption & $4,18,249$ & $4,86,636$ & 11.8 & 18.1 \\
\hline GFCF & $11,32,195$ & $5,99,192$ & 32.0 & 22.3 \\
\hline CIS & 67,328 & 53,336 & 1.9 & 2.0 \\
\hline Valuables & 51,347 & 4,645 & 1.5 & 0.2 \\
\hline Exports & $7,08,546$ & $5,67,961$ & 20.0 & 21.1 \\
\hline Imports & $8,25,788$ & $4,92,286$ & 23.4 & 18.3 \\
\hline Discrepancies & $-9,576$ & 8,908 & -0.3 & 0.3 \\
\hline GDP & $35,35,267$ & $26,89,556$ & & \\
\hline \% Changeover & $\mathbf{5 . 2}$ & $\mathbf{- 2 3 . 9}$ & & \\
\hline
\end{tabular}

Table 3. Estimates of GVA on GDP in Q1 (at 2011-12 Prices) (In Crores) 


\begin{tabular}{|l|l|l|l|l|}
\hline \multirow{2}{*}{ Industry } & \multicolumn{4}{c|}{ April-June (Q1) } \\
\cline { 2 - 5 } & $\mathbf{2 0 1 9 - 2 0}$ & $\mathbf{2 0 2 0 - 2 1}$ & \multicolumn{2}{|c|}{ Rates of GDP(\% } \\
\cline { 3 - 5 } & & & $\begin{array}{c}\mathbf{2 0 1 9}- \\
\mathbf{2 0}\end{array}$ & $\begin{array}{c}\mathbf{2 0 2 0}- \\
\mathbf{2 1}\end{array}$ \\
\hline $\begin{array}{l}\text { Agriculture ,Forestry \& } \\
\text { Fishing }\end{array}$ & $4,39,843$ & $4,54,658$ & 3.00 & 3.40 \\
\hline Mining & & & & \\
\hline Manufacturing & 92,807 & 71,209 & 4.70 & -23.3 \\
\hline Electricity, Gas etc & $5,78,936$ & $3,51,396$ & 3.00 & -39.3 \\
\hline Construction & 81,628 & 75,877 & 8.8 & -7.0 \\
\hline $\begin{array}{l}\text { Trade Hotels transport, } \\
\text { Communication }\end{array}$ & $6,62,828$ & $1,30,750$ & 5.2 & -50.3 \\
\hline Financial, Real Estate & $8,03,322$ & $3,34,284$ & 3.5 & -47.0 \\
\hline Public admin, Defence & $4,17,483$ & $3,60,491$ & 6.0 & -5.30 \\
\hline GVA at Basic Prices & $\mathbf{3 3 , 0 7 , 7 0 7}$ & $\mathbf{2 5 , 5 3 , 3 2 0}$ & $\mathbf{4 . 8}$ & $\mathbf{- 2 2 . 8}$ \\
\hline
\end{tabular}

Above figures clearly shows that except agriculture, forestry \& fishing all other sectors have crashed. The construction sector is the worse hit sector due to lockdown and trade, hotel, transport, communication and service related to the broadcasting is second highest affected sector during lockdown. There are many indicators which are used to estimate the GVA. Some of the main indicators which are highly impacted due to lockdown are listed below.

Table 4. Main indicators which are highly impacted due to lockdown

\begin{tabular}{|l|l|c|c|}
\hline $\begin{array}{l}\text { Sr. } \\
\text { No. }\end{array}$ & \multicolumn{1}{|c|}{ Indicators } & $\begin{array}{c}\text { Q1 } \\
(2019-20)\end{array}$ & $\begin{array}{c}\text { Q1 } \\
(2020-21)\end{array}$ \\
\hline 1 & Railway (Passenger Kms) & -2.2 & -99.5 \\
\hline 2 & $\begin{array}{l}\text { Passenger Handled at } \\
\text { Airport }\end{array}$ & -0.6 & -94.1 \\
\hline 3 & $\begin{array}{l}\text { Sales of Commercial } \\
\text { vehicle }\end{array}$ & -9.5 & -84.8 \\
\hline 4 & Cargo Handled at Airport & -6.5 & -57.2 \\
\hline 5 & IIP (Metallic Minerals) & 17.9 & -43.3 \\
\hline 6 & Production of Cement & 1 & -38.3 \\
\hline
\end{tabular}

To avoid spread of Corona virus from one city to another city or urban areas to rural areas, government had suspended trains and flights for more than 3 months and the results were terrifying. Percentage change is Gross value added (GVA) of railway (passengers Kilometers) and passenger handled airports are -99.5 and -94.1 respectively.

Due to collapse of many economies, millions of people lost their job all over the world. In United States, 881,000 people have lost their job in the month of March. As per experts view, this recession is expected to be deepest but shorter compared to 2008 depression. The 2008 depression was caused by a collapse in the financial markets. Banks were not ready for lending, Credits were completely dried up and housing prices were collapsed and it took years for these markets to restore. Experts also says that current recession won't cause depression and economy of many countries will come on track in third quarter of financial year 2020-21.

\section{IMPACT OF COVID-19 ON INDIAN CONSTRUCTION SECTOR}

Central government responded immediately and declared nation-wide lockdown for initial 21 days and extended step by step for next 2 months. It took few month to lift lockdown with varying rules and regulations with regards to different situations in different areas. All the construction activities were ordered to stop completely. 6 Lakhs of workers from metro cities packed their bags and walked on their foot to their home because of non-availability of work and around 10 lakh workers are in relief camps as per the Centre's submission to petitions in the Supreme Court. Due to the bans on cross city and cross state, supply chain of construction materials disrupted, production of construction material decreased with increase in their prices. Results, increase of financial burden on construction companies. To reduce this financial burden, thousands of employee laid off from the service.

Table: 3 clearly shows that the Construction sector was highly affected sector because of COVID-19 with -50.3\% contraction in GDP. Construction sector is divided in to tree mega segment i.e. Real Estate (Residential and commercial), Infrastructure (Road, 
Dam, Tunnel, Railway, Power and Airports etc.) and Industrial (Textiles, Refineries and Pipeline etc.). The major contributor to GDP contraction was real estate sector because the city like Mumbai, Delhi, Bangalore, Pune etc. were in completely lockdown for long period. Due to the increase in unemployment in almost all sectors due to COVID crises, people lost their buying power which result in real estate companies couldn't sell their ready to sell properties and have faced drastic reduction in cash flows ends in halt of construction activities of ongoing projects even after lifting the lockdown. Infrastructure sector were partially affected by lockdown because most of the infrastructure projects are generally located at remote areas and rural areas were less affected due to COVID-19 virus. Central Government and State Government had given instruction to construction companies to stop all the construction activities only in red zone areas. As per the survey conducted by 30 professionals from construction sector to assess the economic impact of COVID-19 on construction sector, the project implementation cost may not vary much for linear projects like transmission lines, irrigation canals, roads and pipelines but cost may rise by 2 to 5 per cent for the non-linear projects and the cost of skilled labor may rise to $25-30 \%$ whereas the cost of unskilled labor may rise by 10-15\% ( $\underline{\mathrm{KPMG}}$ ). The Infrastructure \& Project Monitoring Division (IPMD) is the project management division of Ministry of Statistics and program Implementation (MoSPI) which monitors the status of Infrastructure projects. As per the data, total numbers of ongoing projects till May-2020 were 1863 (worth 20.65 trillion) and their anticipated cost is around 24.75 trillion (MoSPI).

\section{A. Probable long term effect on construction companies:}

- Government is facing deficits which may results in decrease of demands in projects.

- Companies may face huge debt and liquidity crises.

- Small business and sub-contractors may collapse drastically.

- Revision of contract may come into picture as customer may seek for negotiation and termination.

- Countries may interpolate restriction on international companies.

\section{B. Initiatives by Government Bodies:}

Taking cognizance of the situation created due to COVID-19, Government of India, Ministry of Finance, Department of Expenditure, Procurement policy Division has taken some steps for including COVID-19 as Force Majeure Clause (FMC). It was clarified that the disruption of supply chains due to spread of Corona Virus, it may not be possible for the parties to the contract to fulfill the contractual obligation. Therefore, after fulfilling the due procedure and wherever applicable, parties to the contract may invoke Force Majeure Clause (FMC) for all construction work, Goods and Service Contract and PPP contract with Government agencies. This clause is applicable for the contract obligation which was supposed to be completed on or before 20th February 2020 and shall stand extended for a period not less than three months and not more than 6 months without imposing cost or penalty on the contractor. It was also clarified that implementation of FMC would be held valid only in a situation where the partied to the contract were not in default to the contractual obligation as on 19th February 2020 (MOF, GOI).

Since the big cities were worst hit with COVID-19, development of Real Estate projects were completely at halt. Section 6 of RERA, 2016 is for are entitled for extension of registration on account of force majeure caused by any calamity affecting the current work of and it is clear that COVID-19 pandemic caused by the nature and affecting the development of the projects.

In order to safeguard the interest of stakeholders in real estate projects including homebuyers, financial institutions, developers, real estate agents, regulatory authorities etc., on 29th April 2020 meeting of Central Advisory Council (CAC) was held under the chairmanship of Honorable Minister of Housing and Urban Affairs. After detailed analysis on the situation, unanimously gave recommendation to Regulatory Authority to invoke the COVID-19 as a Force Majeure by issuing the orders/directions, in pursuance of section 37 of RERA read with section 34(f) of the RERA, the registration or extension thereto under Section 5, 6, 7(3) of the RERA to the real estate projects completing on or after 25th March 2020 in their respective jurisdictions. CAC has recommended to make it simple to get implemented easily. In advisory, it was stated that Regulatory Authorities of respective state may issue suitable orders to extend the registration and completion date or revised completion date or extended completion date automatically by 6 months due to outbreak of COVID-19. Further, Regulatory Authorities may, on their own decision, consider to further extend the date of completion of project as per registration for another period up to 3 months. Regulatory Authorities may issue fresh 'Project Registration Certificate 'with revised schedule in each such registered project in their jurisdiction (MoHUA).

A construction company requires BGs equivalent to $10-20 \%$ of its contract value. These are in the form of performance bank guarantees, a guarantee for availing of the mobilization advance, a guarantee for release of the retention money, earnest money guarantee which is usually released after the completion of the projects and that too in a phased manner. Finance Minister announced release of Bank guarantees depending upon the percentage of work completion. "It will result in sufficient liquidity in the hands of companies and will aid them to meet their working capital needs (ICRA).

\section{Actions required by Construction Companies:}

Necessary steps companies can take in order to mitigate the cost overrun and delays in project.

1. Review of Contract Document- Companies have to evaluate the provisions given in the contract in order to find out whether COVID-19 can be included as Force Majeure Clause or not. As per the Central Government guidelines, COVID-19 pandemic 
can be covered under Force Majeure clause. If Owner/Client agrees on it then contractor has to discuss with them for further project approach on this pandemic.

2. Impact Measurement- If owner/client agrees to cover this pandemic under Force Majeure Clause, contractor companies must demonstrate the impact caused.

- Cost- Contractor must have to quantify the damages in the monetary form on the basis of Scope of work and cost incurred for preventive measure.

- Schedule- Contractor must quantify the delays in activities caused by the pandemic in order to claim the extension of time.

- $\quad$ Resources- Contractor must evaluate the impact on availability of resources and quantify the available resources and requires resources (Man, Machine and Material) to complete remaining scope of work.

- Logistics- Since the supply chain of material disturbed completely during lockdown, contractor has evaluate lead time for critical material.

- Quality- Need to assess the impact on quality of work due to non-availability of skilled labor and their limited travel.

3. Update Risk register- Client and contractor should identify the potential future risk associated with current situation caused by the pandemic, assign ownership of each risk and prepare the mitigation plan in order to complete project successfully within stipulated time and budget.

4. Develop Future Plan- Both parties have to develop plan to complete the remaining tasks of scope of work which may include identifying bottleneck, contingency requirement, rescheduling resource plan, evaluate and forecast the schedule of remaining work and identify the task which can be completed by fast tracking method in Project Management Software like Primavera and MSP. Communicate the developed plan with all stakeholders and get their consent on it.

5. Execution of plan- Now all stakeholders will be on same page. Now the final steps are directing, managing and tracking the project work and the work is going in proper direction.

\section{CONCLUSION}

Due to the restriction of human activities as a matter of course there is an improvement in environment. Nevertheless, this epidemic which is taking the lives of people should not be seen a positive change to the environment which was for a short period. Central Government and state governments started rolling back the restriction by issuing revised guidelines in order to save economy from sinking. As a result, there is an improvement in GDP in Q2, 2020-21 but still economy is in negative and government has to take big steps. There are short term and long term impact on construction projects depending on their nature. Government is talking initiative to give relief to construction companies, even though companies have to take steps to manage the crises from three direction i.e. Respond, Recover and Thrive.

\section{REFERENCES}

[1] Saeida Saadat a, Deepak Rawtani, Chaudhery Mustansar Hussain b, "Environmental perspective of COVID-19" Elsevier, Science of the Total Environment 728 (2020) 138870

[2] Snehal Lokhandwala*, Pratibha Gautam, "Indirect impact of COVID-19 on environment: A brief study in Indian context" Elsevier, Environmental Research 188 (2020) 109807

[3] Frederic Dutheil, Julien S. Baker, Valentin Navel, "COVID-19 as a factor influencing air pollution? Elsevier, Environmental Pollution 263 (2020) 114466

[4] Hasan Eroğlu, "Effects of Covid-19 outbreak on environment and renewable energy sector" Environment, Development and Sustainability, Springer Nature B.V. 2020

[5] Danny Murguia, Alonso Urbina Sanchez "Complex Production Systems: Non-Linear and Non-repetitive Projects" 26th Annual Conference of the International Group for Lean Construction (IGLC), González, V.A. (ed.), Chennai, India, pp. 858-868

[6] KPMG Report "COVID-19: Assessment of economic impact on Construction Sector in India" May 2020

[7] Abhinraj R S "India: Impact of COVID-19 on Construction and Engineering Sector" Researchgate/ 340966338, April 2020. 


\section{AUTHORS}

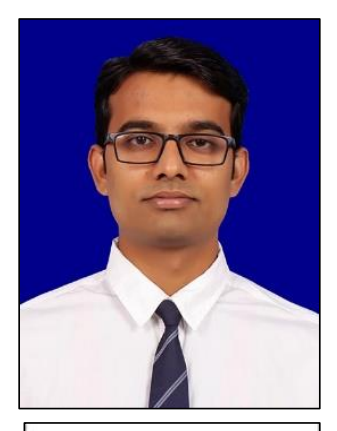

Satish Tanaji Chavhan, currently working as Project Coordinator (PMU, Power and Energy), SMEC India Private Limited, Gurugram, India. He is B.Tech in Electrical Engineering from RIT (An Autonomous Institute), Sangli, completed Post-Graduation Program in Project Engineering \& Management from (NICMAR, Pune), MBA in Operations Management from Himalayan University, Post-Graduation Program in Thermal Power Technology from ICOM, Nagpur. His research interests are advances in Project Management, Power Projects and Flexible AC Transmission Systems (FACTS) controllers.

E-mail: Satish.Chavhan@smec.com

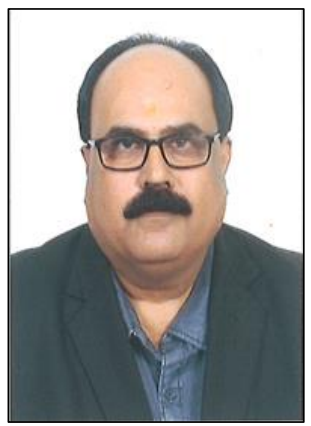

Sandip Srivastava currently working as Project Manager KUIDFC/SWW Experts/Social Experts (PMU, Water and Environmental), SMEC India Private Limited, Gurugram, India. He is Qualified B.Tech Civil Engineering with $1^{\text {st }}$ Class Distinction, Recipient of Jubilee Merit Scholarship from Tata Steel, PG Diploma in System Applications, Qualified Six Sigma Quality External/Internal Auditor. Life Member All India Water Works Association [LM-2620] and Bachelor of Arts in Sociology. Having 30 Years of experience in Construction Sectors, Various Infra Projects with KBPL IOCL], Engineers India Limited, PMC Projects and Construction \& Supervision of Industrial Corridors of Model Economic Townships [Reliance], Jhajjar Haryana, Sinar Mas Pulp \& Paper ITPL Bengaluru etc including Overseas Projects Dubai Sewerage \& Waste water projects with Black \& Veach/Mott/Skoda exports.

E-mail: sandip.srivastava@smec.com

Correspondence Author - Sandip Srivastava, sandip.srivastava@ smec.com, +91-7977448652. 